\title{
Effect Of Examination Stress On The Blood Pressure Of Secondary School Students In Oroke High School Akungba - Akoko, Ondo State, South Western Nigeria
}

\author{
N. O. Ajayi, and J. S. Adegboro
}

\begin{abstract}
Background: Examination stress is caused by various stressors: the fear of inadequate preparation for the exam and fear of failing it, the need to pass very well in the exam to satisfy the parental and guardian expectation and the extra effort made to work harder, burning the midnight oil over the preparation for the examination. The aim of this study is to use the data of blood pressure to find out the effect of examination stress on the various Nigerian secondary school classes.

Method: Quasi experimental research design was used for this studyю A sample of (650) respondents was selected using stratified sampling technique. Digital sphygmomanometer was used to measure the actual blood pressure readings of the respondents. The readings were taken twice on each occasion with at least thirty minutes interval in sitting positions. The measurements were carried out three times during the study, two weeks after resumption for the second term of 2017/2018 academic year, two weeks before the second term examination and four weeks after the terminal examination.

Results: The results show that the mean systolic blood pressure two weeks before the start of the examination is generally higher for all the classes than their values at the beginning of the term and their values at four weeks after the examination. Since blood pressure increases with stress [1] - [5].

Conclusion: examination stress increases towards the start of examination and reduces after it, males and females differ in their experience of stress imposed by academic examination, and blood pressure increases with stress.
\end{abstract}

Index Terms - Examination, blood pressure, hormone, stressor, stress.

\section{INTRODUCTION}

Stress has been defined in many ways as a state of psychological arousal that results when the external demand is beyond what one can cope with [6] - [8]. Stress therefore starts when the emotional, environmental and physical needs of the individual start to compete with one another and exceed that which one can cope with. Stress is caused by various factors called stressors. These stressors are fear of the unknown or of failure, frustration, conflict, poor relationships, family problems, insecurity, anxiety, high workload and so on [9].

Academic stressors among other things include overloaded study programs, too much academic assignment to tackle, the student's perception of the extensive knowledge-base

Published on June 4, 2020.

N. O. Ajayi, Adekunle Ajasin University, Akungba Akoko, Ondo State, Nigeria.

J. S. Adegboro, Adekunle Ajasin University, Akungba Akoko, Ondo State, Nigeria.

(corresponding e-mail: adejossy95@yahoo.com) required and his perception of the inadequate time to develop it [10], studying for and taking exams, with a large amount of content to master before it [11], [12]; fear of failure at academic examinations [13], and lack of money to take care of needs in the school especially during the examination period. One major contributor to stress in secondary schools and colleges is the great expectation of parents over their wards to achieve good marks in examinations and to cope well with competition in the class.

Stress has been found to be a major contributing factor to academic performance. Although Kaplan and Shadock recognized an optimal level of stress that can enhance learning ability [14], Niemi and Vainiomali argued that too much stress can cause physical and mental health problems and may affect academic achievement [15] - [18].

Stress can cause hypertension through repeated blood pressure elevation as well as by stimulation of the nervous system to produce large amounts of vaso-constricting hormones that increase blood pressure. Acute stress can induce transient elevation of blood pressure [19], but it is still unclear whether stress can result in sustained elevation of blood pressure and hypertension. Markovitz and his group supported the contention that high levels of chronic anxiety may produce increased sympathetic tone of sufficient degree and duration to result in sustained hypertension in certain individuals [20].

Factors affecting blood pressure through stress include white coat hypertension, job strain and race, social environment and emotional stress. When one risk factor is coupled with other stress producing factors, the effect on blood pressure is multiplied. Increases in blood pressure related to stress can be dramatic. Once the stressor disappears, blood pressure returns to normal. However, if temporary spikes in blood pressure occur often enough, they can damage blood vessels, heart and kidneys in a way like long term high blood pressure. So far, questionnaire has been a major instrument used to assess stress. Despite the techniques sometimes put in place to check the truthfulness of response, this method is highly subjective and can lead to some errors where participants will answer questions in a socially desirable manner to avoid the stigma associated with admitting personal inadequacies.

The Nigerian secondary school system is divided into two schools: the junior secondary (JS) and the senior secondary 
(SS) schools. A normal student will be in JS1 class in the first year of his secondary school career, JS2 class in the second year, JS3 class in the third year, SS1 class in the fourth year, SS2 class in the fifth year and SS3 class in the sixth year at the end of which he will sit for his first national examination of the West African Examination Council (WAEC) and or other such examinations.

Our primary objective in this study therefore is to use the data of blood pressure to estimate the mean examination stress experienced by the group of students in each of the secondary school classes (JS1,JS2, JS3, SS1 and SS2) of Oroke High School, Akungba Akoko, Ondo State, Nigeria, two weeks after resumption, two weeks to the terminal examination and four weeks after the terminal examination of the second term of the 2017/2018 school year.

\section{MAterials AND METHOD}

\section{A. How data were collected}

Quasi experimental research design was used for this study. The population of the study comprises all students of Oroke grammar school Akungba Akoko. A sample of (650) respondents was selected using stratified sampling technique. Students have been distributed into different classes in the school before the study and effort was made not to disrupt the natural distribution. Opportunistic sampling technique was used to select all available and willing respondents into the study. In carrying out this research, two instruments were used. The first instrument, sought information on the bio-data of the respondents, it is a self-constructed, structured, and closed ended questionnaire designed and built around the research questions, while the second instrument is digital sphygmomanometer, used to monitor and record the actual systolic blood pressure (SBP) and diastolic blood pressure (DBP) readings of the respondents. The readings were taken twice on each occasion with at least thirty minutes interval in sitting position. This was done three times during the study. The first was done two weeks into the second term of 2017/2018 academic session when students newly resumed from the New Year holidays. It was assumed that at that time, academic stress will be at the lowest ebb as there was no examination to prepare for to spur any anxiety among students in the various classes. The second administration came up two week before the second term examination when all the respondents were seriously preparing for the second term examination, while the third and last administration was carried out two weeks after the resumption for the third term from a two week holidays. At this period, the respondents have relaxed from the rigor of academics for about four weeks after their examination and it is expected that academic stress would have gone down. The first instrument was validated by three experts in health education and the reliability was determined using test re-test method. A coefficient of 0.95 was obtained and this was considered adequate for the study. The second instrument was calibrated and found to be good enough for the study.

Data was analyzed with descriptive and inferential statistics to answer questions and test the hypotheses raised for the research. The analysis was done with the use of Statistical Package for Social Sciences (SPSS) version 20, graph and correlation statistics at 0.05 level of significance.

\section{B. Sample size and sampling}

There are three categories of students in local secondary schools in the South Western Nigeria:

- (I) those who work during the holiday period, making them to be work stressed at the beginning of the term, and making their blood pressure to be higher than expected when they resume school;

- (II) those who work during the holiday period and also at home after the school hours, making their blood pressure to be affected by both work stress and academic stress;

- (III) those who do not work during the holidays and at home after the school period, making them to be relaxed and to have relatively normal blood pressure when they resume school. For this group, their blood pressure will be raised only by academic/examination stress.

Therefore, the data selected for this work are those obtained from the third group where the blood pressure at the beginning of the school term is lower than the blood pressure two weeks to the terminal examination.

\section{Statistical Analysis}

Stress can raise the blood pressure of a subject [1], not necessarily above the normal pressure, and causing the mean blood pressure of a stressed group to be raised. The analysis of this work therefore considers the mean blood pressure of a group when it is not stressed and when it is stressed to be able to find the effect of examination stress on mean blood pressure of the group. The data were arranged class by class to assess the examination stress on each class and statistically treated, using statistical software SSPS version 20.0 to calculate the mean and the standard deviation of the systolic blood pressure and diastolic blood pressure of the students in each class when they resume studies at the beginning of the second term, two weeks to the second term examination and two weeks after resumption of the third term from a two-week holidays.

\section{REsults}

Table I shows the mean age, mean systolic and diastolic blood pressure of male and female students in the different classes in the school, two weeks after the beginning of the school term when the students just resumed and academic stress has not set in. The mean age of the classes increases from 12 years to 16 years as one goes from the lowest class (JS1) to the high classes. The Table I shows the variation of the mean systolic blood pressure against age respectively for males and females at the beginning of the second term when no academic work has started, and the students are therefore not academically stressed.

The Table II shows that the mean systolic blood pressure at two weeks to the examination is generally higher than its value at the beginning of term but decreases after the examination to lower levels for both male and female students. 
Table I: Demography Profile Of The Study SubJects In The Second Term Of 2017/2018 School Year

\begin{tabular}{|c|c|c|c|c|c|c|c|c|}
\hline \multirow{3}{*}{ Class } & \multicolumn{4}{|c|}{ Males } & \multicolumn{4}{|c|}{ Females } \\
\hline & \multirow{2}{*}{$\begin{array}{l}\text { Number of } \\
\text { students }\end{array}$} & \multirow{2}{*}{$\begin{array}{l}\text { Mean age } \\
\text { (years) }\end{array}$} & \multicolumn{2}{|c|}{$\begin{array}{l}\text { Mean Blood Pressure at the } \\
\text { beginning of } 2^{\text {nd }} \text { term }\end{array}$} & \multirow{2}{*}{$\begin{array}{c}\text { Number } \\
\text { of } \\
\text { students }\end{array}$} & \multirow{2}{*}{$\begin{array}{l}\text { Mean age } \\
\text { (years) }\end{array}$} & \multicolumn{2}{|c|}{$\begin{array}{l}\text { Mean Blood Pressure at } \\
\text { the beginning of } 2^{\text {nd }} \text { term }\end{array}$} \\
\hline & & & $\begin{array}{l}\text { SBP } \\
\pm \text { SD }\end{array}$ & $\begin{array}{l}\text { DBP } \\
\pm \text { SD }\end{array}$ & & & $\mathrm{SBP} \pm \mathrm{SD}$ & $\mathrm{DBP} \pm \mathrm{SD}$ \\
\hline JS1 & 41 & $\begin{array}{l}11.9 \\
\pm 1.2\end{array}$ & $\begin{array}{c}93.8 \\
\pm 10.2\end{array}$ & $\begin{array}{l}59.3 \\
\pm 8.3\end{array}$ & 36 & $\begin{array}{l}11.1 \\
\pm 1.4\end{array}$ & $\begin{array}{c}99.9 \\
\pm 10.8\end{array}$ & $\begin{array}{l}61.8 \\
\pm 9.7\end{array}$ \\
\hline JS2 & 36 & $\begin{array}{r}13.0 \\
\pm 1.0 \\
\end{array}$ & $\begin{array}{r}97.2 \\
\pm 13.7 \\
\end{array}$ & $\begin{array}{r}64.0 \\
\pm 8.5 \\
\end{array}$ & 43 & $\begin{array}{r}12.5 \\
\pm 1.3 \\
\end{array}$ & $\begin{array}{r}98.6 \\
\pm 10.8 \\
\end{array}$ & $\begin{array}{c}64.2 \\
\pm 10.8 \\
\end{array}$ \\
\hline JS3 & 19 & $\begin{array}{l}13.5 \\
\pm 1.6\end{array}$ & $\begin{array}{c}104.6 \\
\pm 9.1\end{array}$ & $\begin{array}{l}65.6 \\
\pm 7.2\end{array}$ & 40 & $\begin{array}{r}13.3 \\
\pm 1.4\end{array}$ & $\begin{array}{l}101.5 \\
\pm 13.6\end{array}$ & $\begin{array}{l}62.2 \\
\pm 8.2\end{array}$ \\
\hline SS1 & 34 & $\begin{array}{r}15.2 \\
\pm 1.3 \\
\end{array}$ & $\begin{array}{r}103.5 \\
\pm 13.9 \\
\end{array}$ & $\begin{array}{c}64.9 \\
\pm 12.0 \\
\end{array}$ & 34 & $\begin{array}{r}14.8 \\
\pm 0.9 \\
\end{array}$ & $\begin{array}{l}101.7 \\
\pm 9.3 \\
\end{array}$ & $\begin{array}{r}63.2 \\
\pm 12.1 \\
\end{array}$ \\
\hline $\mathrm{SS} 2$ & 20 & $\begin{array}{r}15.8 \\
\pm 1.2 \\
\end{array}$ & $\begin{array}{l}103.7 \\
\pm 8.9 \\
\end{array}$ & $\begin{array}{c}68.1 \\
\pm 12.2 \\
\end{array}$ & 50 & $\begin{array}{r}14.7 \\
\pm 1.2 \\
\end{array}$ & $\begin{array}{l}107.6 \\
\pm 9.3 \\
\end{array}$ & $\begin{array}{r}69.2 \\
\pm 9.4 \\
\end{array}$ \\
\hline
\end{tabular}

TABLE II: MEAN VALUES OF SBP OF GROUPS OF MALE AND FEMALE STUDENTS IN DIFFERENT CLASSES IN THE SECOND TERM OF $2017 / 2018$ SCHOOL YEAR, ON RESUMPTION, 2 WEEKS BEFORE AND 4 WEEKS AFTER THE TERMINAL EXAMINATION

\begin{tabular}{|c|c|c|c|c|c|c|c|c|c|c|}
\hline \multirow{3}{*}{ Class } & \multicolumn{5}{|c|}{ Males } & \multicolumn{5}{|c|}{ Females } \\
\hline & \multirow{2}{*}{$\begin{array}{c}\text { Number } \\
\text { of } \\
\text { students }\end{array}$} & \multirow{2}{*}{$\begin{array}{c}\text { Mean } \\
\text { age } \\
\text { (years) }\end{array}$} & \multicolumn{3}{|c|}{ Mean SBP \pm SD } & \multirow{2}{*}{$\begin{array}{c}\text { Number } \\
\text { of } \\
\text { students }\end{array}$} & \multirow[b]{2}{*}{$\begin{array}{l}\text { Mean age } \\
\text { (years) }\end{array}$} & \multicolumn{3}{|c|}{ Mean SBP \pm SD } \\
\hline & & & $\begin{array}{c}\text { Beginning of } \\
\text { term }\end{array}$ & $\begin{array}{l}2 \text { weeks } \\
\text { to exam }\end{array}$ & $\begin{array}{c}4 \text { weeks } \\
\text { after exam }\end{array}$ & & & $\begin{array}{c}\text { Beginning } \\
\text { of term }\end{array}$ & $\begin{array}{l}2 \text { weeks } \\
\text { to exam }\end{array}$ & $\begin{array}{c}4 \text { weeks } \\
\text { after exam }\end{array}$ \\
\hline JS1 & 41 & $\begin{array}{r}11.9 \\
\pm 1.2 \\
\end{array}$ & $\begin{array}{r}93.8 \\
\pm 10.2 \\
\end{array}$ & $\begin{array}{l}104.9 \\
\pm 10.1 \\
\end{array}$ & $\begin{array}{c}97.0 \pm \\
8.1\end{array}$ & 36 & $\begin{array}{r}11.1 \\
\pm 1.4 \\
\end{array}$ & $\begin{array}{c}99.9 \\
\pm 10.8 \\
\end{array}$ & $\begin{array}{c}106.2 \\
\pm 9.7\end{array}$ & $\begin{array}{l}96.5 \\
\pm 8.4 \\
\end{array}$ \\
\hline JS2 & 36 & $\begin{array}{l}13.0 \\
\pm 1.0 \\
\end{array}$ & $\begin{array}{r}97.2 \\
\pm 13.7 \\
\end{array}$ & $\begin{array}{r}110.0 \\
\pm 10.2 \\
\end{array}$ & $\begin{array}{c}101.0 \pm \\
13.3\end{array}$ & 43 & $\begin{array}{r}12.5 \\
\pm 1.3 \\
\end{array}$ & $\begin{array}{c}98.6 \\
\pm 10.8 \\
\end{array}$ & $\begin{array}{l}108.0 \\
\pm 19.0 \\
\end{array}$ & $\begin{array}{c}99.0 \\
\pm 10.1 \\
\end{array}$ \\
\hline JS3 & 19 & $\begin{array}{r}13.5 \\
\pm 1.6 \\
\end{array}$ & $\begin{array}{c}104.6 \\
\pm 9.1 \\
\end{array}$ & $\begin{array}{c}110.8 \pm \\
9.8\end{array}$ & $\begin{array}{l}102.9 \\
\pm 11.2 \\
\end{array}$ & 40 & $\begin{array}{r}13.3 \\
\pm 1.4 \\
\end{array}$ & $\begin{array}{l}101.5 \\
\pm 13.6 \\
\end{array}$ & $\begin{array}{l}111.9 \\
\pm 17.5 \\
\end{array}$ & $\begin{array}{l}100.0 \\
\pm 10.0 \\
\end{array}$ \\
\hline SS1 & 34 & $\begin{array}{r}15.2 \\
\pm 1.3 \\
\end{array}$ & $\begin{array}{l}103.5 \\
\pm 13.9 \\
\end{array}$ & $\begin{array}{l}111.9 \\
\pm 10.6 \\
\end{array}$ & $\begin{array}{c}104.2 \\
\pm 9.2 \\
\end{array}$ & 34 & $\begin{array}{l}14.8 \\
\pm 0.9 \\
\end{array}$ & $\begin{array}{c}101.7 \\
\pm 9.3 \\
\end{array}$ & $\begin{array}{l}115.5 \\
\pm 9.7 \\
\end{array}$ & $\begin{array}{l}101.7 \\
\pm 7.5 \\
\end{array}$ \\
\hline $\mathrm{SS} 2$ & 20 & $\begin{array}{r}15.8 \\
\pm 1.2 \\
\end{array}$ & $\begin{array}{l}103.7 \\
\pm 8.9 \\
\end{array}$ & $\begin{array}{l}111.6 \\
\pm 10.4 \\
\end{array}$ & $\begin{array}{l}103.6 \\
\pm 10.9 \\
\end{array}$ & 50 & $\begin{array}{r}14.7 \\
\pm 1.2 \\
\end{array}$ & $\begin{array}{l}107.6 \\
\pm 9.3 \\
\end{array}$ & $\begin{array}{l}115.7 \\
\pm 9.0 \\
\end{array}$ & $\begin{array}{l}102.0 \\
\pm 7.7 \\
\end{array}$ \\
\hline
\end{tabular}

TABLE III A: COMPARISON OF MEAN SBP AT BEGINNING OF TERM WITH THE MEAN SBP AT 2 WEEKS TO TERMINAL EXAM

\begin{tabular}{|c|c|c|c|c|c|c|c|c|c|c|}
\hline \multirow{3}{*}{ Class } & \multicolumn{5}{|c|}{ Males } & \multicolumn{5}{|c|}{ Females } \\
\hline & \multirow{2}{*}{$\begin{array}{c}\text { Number } \\
\text { of } \\
\text { students }\end{array}$} & \multicolumn{2}{|c|}{ Mean SBP \pm SD } & \multicolumn{2}{|c|}{$\begin{array}{c}\text { Difference in } \\
\text { mean SBP }\end{array}$} & \multirow{2}{*}{$\begin{array}{c}\text { Number } \\
\text { of } \\
\text { students }\end{array}$} & \multicolumn{3}{|c|}{ Mean $\mathrm{SBP} \pm \mathrm{SD}$} & \multirow{2}{*}{$\begin{array}{c}\text { Difference in } \\
\text { mean SBP }\end{array}$} \\
\hline & & $\begin{array}{c}\text { Beginning } \\
\text { of term }\end{array}$ & $\begin{array}{l}2 \text { weeks } \\
\text { to exam }\end{array}$ & $\mathrm{t}_{\text {calc }}$ & $\mathrm{t}_{0.05}$ & & $\begin{array}{c}\text { Beginning } \\
\text { of term }\end{array}$ & $\begin{array}{l}2 \text { weeks } \\
\text { to exam }\end{array}$ & $\mathrm{t}_{\text {calc }}$ & \\
\hline JS1 & 41 & $\begin{array}{c}93.8 \\
\pm 10.2 \\
\end{array}$ & $\begin{array}{l}104.9 \\
\pm 10.1 \\
\end{array}$ & 4.95 & 1.66 & 36 & $\begin{array}{c}99.9 \\
\pm 10.8 \\
\end{array}$ & $\begin{array}{c}106.2 \\
\pm 9.7 \\
\end{array}$ & 2.60 & 1.67 \\
\hline JS2 & 36 & $\begin{array}{c}97.2 \\
\pm 13.7 \\
\end{array}$ & $\begin{array}{l}110.0 \\
\pm 10.2 \\
\end{array}$ & 4.50 & 1.67 & 43 & $\begin{array}{c}98.6 \\
\pm 10.8 \\
\end{array}$ & $\begin{array}{l}108.0 \\
\pm 19.0 \\
\end{array}$ & 2.85 & 1.66 \\
\hline JS3 & 19 & $\begin{array}{c}104.6 \\
\pm 9.1\end{array}$ & $\begin{array}{c}110.8 \pm \\
9.8\end{array}$ & 4.01 & 1.69 & 40 & $\begin{array}{l}101.5 \\
\pm 13.6\end{array}$ & $\begin{array}{l}111.9 \\
\pm 17.5\end{array}$ & 3.08 & 1.67 \\
\hline SS1 & 34 & $\begin{array}{l}103.5 \\
\pm 13.9 \\
\end{array}$ & $\begin{array}{l}111.9 \\
\pm 10.6\end{array}$ & 2.80 & 1.67 & 34 & $\begin{array}{c}101.7 \\
\pm 9.3\end{array}$ & $\begin{array}{c}115.5 \\
\pm 9.7 \\
\end{array}$ & 4.34 & 1.67 \\
\hline SS2 & 20 & $\begin{array}{l}103.7 \\
\pm 8.9\end{array}$ & $\begin{array}{l}111.6 \\
\pm 10.4\end{array}$ & 2.50 & 1.69 & 50 & $\begin{array}{l}107.6 \\
\pm 9.3\end{array}$ & $\begin{array}{l}115.7 \\
\pm 9.0\end{array}$ & 4.43 & 1.66 \\
\hline
\end{tabular}

TABLE III B: COMPARISON OF MEAN SBP AT BEGINNING OF TERM WITH THE MEAN SBP AT 4 WEEKS AFTER THE TERMINAL EXAM

\begin{tabular}{|c|c|c|c|c|c|c|c|c|c|c|}
\hline \multirow{3}{*}{ Class } & \multicolumn{5}{|c|}{ Males } & \multicolumn{5}{|c|}{ Females } \\
\hline & \multirow{2}{*}{$\begin{array}{c}\text { Number } \\
\text { of } \\
\text { students }\end{array}$} & \multicolumn{2}{|c|}{ Mean $\mathrm{SBP} \pm \mathrm{SD}$} & \multicolumn{2}{|c|}{$\begin{array}{c}\text { Difference in } \\
\text { mean SBP }\end{array}$} & \multirow{2}{*}{$\begin{array}{c}\text { Number } \\
\text { of } \\
\text { students }\end{array}$} & \multicolumn{3}{|c|}{ Mean $\mathrm{SBP} \pm \mathrm{SD}$} & \multirow{2}{*}{$\begin{array}{c}\text { Difference in } \\
\text { mean SBP } \\
\mathrm{t}_{0.05}\end{array}$} \\
\hline & & $\begin{array}{l}\text { Beginning } \\
\text { of term }\end{array}$ & $\begin{array}{l}\text { wks } \\
\text { after } \\
\text { exam }\end{array}$ & $\mathrm{t}_{\text {calc }}$ & $\mathrm{t}_{0.05}$ & & $\begin{array}{l}\text { Beginning } \\
\text { of term }\end{array}$ & $\begin{array}{l}\text { 4wks } \\
\text { after } \\
\text { exam }\end{array}$ & $\mathrm{t}_{\text {calc }}$ & \\
\hline JS1 & 41 & $\begin{array}{c}93.8 \\
\pm 10.2\end{array}$ & $\begin{array}{r}97.0 \\
\pm 8.1\end{array}$ & 1.59 & 1.66 & 36 & $\begin{array}{c}99.9 \\
\pm 10.8\end{array}$ & $\begin{array}{r}96.5 \\
\pm 8.4\end{array}$ & -1.49 & 1.67 \\
\hline $\mathrm{JS} 2$ & 36 & $\begin{array}{c}97.2 \\
\pm 13.7 \\
\end{array}$ & $\begin{array}{c}101.0 \pm \\
13.3\end{array}$ & 1.19 & 1.67 & 43 & $\begin{array}{c}98.6 \\
\pm 10.8 \\
\end{array}$ & $\begin{array}{c}99.0 \\
\pm 10.1 \\
\end{array}$ & 0.18 & 1.66 \\
\hline JS3 & 19 & $\begin{array}{l}104.6 \\
\pm 9.1\end{array}$ & $\begin{array}{l}102.9 \\
\pm 11.2\end{array}$ & 1.33 & 1.69 & 40 & $\begin{array}{l}101.5 \\
\pm 13.6\end{array}$ & $\begin{array}{l}100.0 \\
\pm 10.0\end{array}$ & -0.68 & 1.67 \\
\hline SS1 & 34 & $\begin{array}{l}103.5 \\
\pm 13.9\end{array}$ & $\begin{array}{l}104.2 \\
\pm 9.2\end{array}$ & 0.24 & 1.67 & 34 & $\begin{array}{l}101.7 \\
\pm 9.3\end{array}$ & $\begin{array}{l}101.7 \\
\pm 7.5\end{array}$ & $=1.85$ & 1.67 \\
\hline SS2 & 20 & $\begin{array}{l}103.7 \\
\pm 8.9\end{array}$ & $\begin{array}{l}103.6 \\
\pm 10.9\end{array}$ & -0.03 & 1.69 & 50 & $\begin{array}{l}107.6 \\
\pm 9.3\end{array}$ & $\begin{array}{l}102.0 \\
\pm 7.7\end{array}$ & -3.28 & 1.66 \\
\hline
\end{tabular}


TABLE IV A: MEAN VALUES OF DBP OF GROUPS OF MALE AND FEMALE STUDENTS IN DIFFERENT CLASSES IN THE SECOND TERM OF $2017 / 2018$ SCHOOL YEAR, ON RESUMPTION, TWO WEEKS BEFORE AND FOUR WEEKS AFTER THE TERMINAL EXAMINATION

\begin{tabular}{|c|c|c|c|c|c|c|c|c|c|c|}
\hline \multirow[b]{3}{*}{ Class } & \multicolumn{5}{|c|}{ Males } & \multicolumn{5}{|c|}{ Females } \\
\hline & \multirow[b]{2}{*}{$\begin{array}{l}\text { Number } \\
\text { of } \\
\text { Students }\end{array}$} & \multirow[b]{2}{*}{$\begin{array}{l}\text { Mean } \\
\text { age } \\
\text { (years) }\end{array}$} & \multicolumn{3}{|c|}{ Mean DBP \pm SD } & \multirow[b]{2}{*}{$\begin{array}{c}\text { Number } \\
\text { of } \\
\text { Students }\end{array}$} & \multirow[b]{2}{*}{$\begin{array}{l}\text { Mean } \\
\text { age } \\
\text { (years) }\end{array}$} & \multicolumn{3}{|c|}{ Mean DBP \pm SD } \\
\hline & & & $\begin{array}{l}\text { Beginning } \\
\text { of term }\end{array}$ & $\begin{array}{l}2 \text { weeks } \\
\text { to exam }\end{array}$ & $\begin{array}{c}4 \text { weeks } \\
\text { after } \\
\text { exam }\end{array}$ & & & $\begin{array}{l}\text { Beginning of } \\
\text { term }\end{array}$ & $\begin{array}{l}2 \text { weeks } \\
\text { to exam }\end{array}$ & $\begin{array}{c}4 \text { weeks } \\
\text { after } \\
\text { exam }\end{array}$ \\
\hline JS1 & 41 & $\begin{array}{l}12.1 \\
\pm 1.4\end{array}$ & $\begin{array}{r}60.1 \\
\pm 8.8\end{array}$ & $\begin{array}{r}63,1 \\
\pm 9.6\end{array}$ & $\begin{array}{r}58.3 \\
\pm 7.0\end{array}$ & 36 & $\begin{array}{l}11.1 \\
\pm 1.4\end{array}$ & $\begin{array}{r}62.6 \\
\pm 9.4\end{array}$ & $\begin{array}{r}63.8 \\
\pm 7.6\end{array}$ & $\begin{array}{c}59.6 \\
\pm 10.5\end{array}$ \\
\hline JS2 & 36 & $\begin{array}{l}13.1 \\
\pm 1.0\end{array}$ & $\begin{array}{r}65.2 \\
\pm 9.6 \\
\end{array}$ & $\begin{array}{r}65.0 \\
\pm 7.2\end{array}$ & $\begin{array}{r}61.1 \\
\pm 6.9\end{array}$ & 43 & $\begin{array}{r}12.6 \\
\pm 1.3\end{array}$ & $\begin{array}{c}68.4 \\
\pm 11.5\end{array}$ & $\begin{array}{l}66.4 \\
\pm 8.8\end{array}$ & $\begin{array}{c}63.6 \\
\pm 11.0\end{array}$ \\
\hline JS3 & 19 & $\begin{array}{l}13.3 \\
\pm 1.6\end{array}$ & $\begin{array}{l}65.5 \\
\pm 6.8\end{array}$ & $\begin{array}{l}65.3 \\
\pm 7.1 \\
\end{array}$ & $\begin{array}{c}60.5 \\
\pm 14.0\end{array}$ & 40 & $\begin{array}{r}13.2 \\
\pm 1.3\end{array}$ & $\begin{array}{r}62.7 \\
\pm 8.3\end{array}$ & $\begin{array}{l}63.7 \\
\pm 8.7\end{array}$ & $\begin{array}{c}57.8 \\
\pm 11.2\end{array}$ \\
\hline SS1 & 34 & $\begin{array}{l}15.1 \\
\pm 1.3\end{array}$ & $\begin{array}{c}68.1 \\
\pm 12.1\end{array}$ & $\begin{array}{c}64.7 \\
\pm 10.2\end{array}$ & $\begin{array}{c}64.7 \\
\pm 11.4\end{array}$ & 34 & $\begin{array}{l}14.8 \\
\pm 0.9\end{array}$ & $\begin{array}{c}64.1 \\
\pm 11.9\end{array}$ & $\begin{array}{r}66.1 \\
\pm 9.1\end{array}$ & $\begin{array}{c}59.1 \\
\pm 7.6\end{array}$ \\
\hline $\mathrm{SS} 2$ & 20 & $\begin{array}{l}16.1 \\
\pm 1.4\end{array}$ & $\begin{array}{c}71.7 \\
\pm 14.1\end{array}$ & $\begin{array}{r}64.4 \\
\pm 7.3\end{array}$ & $\begin{array}{r}58.2 \\
\pm 8.2\end{array}$ & 50 & $\begin{array}{r}14.6 \\
\pm 1.2\end{array}$ & $\begin{array}{r}70.0 \\
\pm 8.3\end{array}$ & $\begin{array}{r}67.0 \\
\pm 9.0\end{array}$ & $\begin{array}{l}61.1 \\
\pm 6.2\end{array}$ \\
\hline
\end{tabular}

Table III A shows that the differences between the mean SBP at two weeks after resumption and 2 weeks to the terminal exam for both males and females at the various classes are significantly different at $5 \%$ significant level $(\mathrm{P}>0.05)$. On the other hand, the differences between the mean SBP at two weeks after resumption and four weeks after the terminal exam for both males and females at the various classes are not significantly different at $5 \%$ significant level $(\mathrm{P}<0.05)$.

TABLE IV B: ANALYSIS OF VARIANCE FOR DATA IN TABLE IV A

\begin{tabular}{|c|c|c|c|c|c|}
\hline ANOVA & $\begin{array}{c}\text { Sum of } \\
\text { Squares }\end{array}$ & $\begin{array}{c}\text { Degree } \\
\text { of } \\
\text { freedom }\end{array}$ & $\begin{array}{c}\text { Mean } \\
\text { Square }\end{array}$ & Alpha & 0.05 \\
\hline Sources & SS & $D f$ & MS & F & P value \\
\hline CLASS & 73.71133 & 4 & 18.42783 & 3.481131 & 0.025889 \\
\hline DBPS & 173.359 & 5 & 34.6718 & 6.549717 & 0.000925 \\
\hline Error & 105.8727 & 20 & 5.293633 & & \\
\hline Total & 352.943 & 29 & & & \\
\hline
\end{tabular}

DBPS: cells for both males and females in each class.

There is no significant difference in the values of DBP at two weeks from the beginning of term, at two weeks to the exam and at four weeks after the exam, showing that all the values of SBP belong to the same population as $\mathrm{F}=6.5497$ $(\mathrm{P}<0.05)$.

\section{DISCUSSION}

Table II shows the mean values of the systolic blood pressure with their standard deviation at the beginning of the second term, two weeks to the second term terminal examination and four weeks after the examination. The result shows that the mean systolic blood pressure of secondary school students is higher just before an academic examination than when there is no examination. In Table III a, the calculated values of student's $t$, for the difference between the SBP at the beginning of the term and at 2 weeks to the terminal exam both for the males and the females, is generally greater than their Table values at 5\% level of significance, showing there is a significant difference between the two.

The reason for this may be associated with the stressors taking place at this time [1] - [5]. Examination time is the time when students suffer from emotional stress caused by the fear of inadequate preparation for the exam and fear of failing it. They also suffer from the need to pass very well in the exam to satisfy the parental and guardian expectation. Another stressor taking place at this time is from the extra effort that students make to work harder, burning the night oil over the preparation for the examination. When these stress producing factors couple with one another, the effect on blood pressure is multiplied.

The examination stress experienced by students is actually a combination of physical and mental stress [8], [21], [22] where each has its separate effect on the blood pressure. The total effect of examination stress thus depends on these stressors and the students' stress coping strategies. Stress causes a surge of hormones which raises the blood pressure [23] and helps to mobilize a lot of energy to deal with difficult situations. One of the most important hormones released is cortisol; in response to which the body produces other hormones to counteract its effect [21].

Both the males and females produce oxytocin which is known to calm down the body and induce relaxation. The females produce more oxytocin than the males, making them to be more relaxed than males and thus to be more prone to perceiving stress much earlier than the males. The males in addition produce vasopressin which is known to promote the sense of taking risk, making them to be prone to ignoring stress and to thereby cope much more easily with physical stress than the females. Thus, the feeling of perceived stress is therefore higher in females than in males [24] - [27].

Because males are prone to ignoring stress, they will continue to stress themselves more and produce more hormones that will raise their blood pressure, thus making their blood pressure to be higher than that of the females under the same age. This conclusion may explain why the mean systolic blood pressure of males is higher than for females. However, the action of oxytocin in females that increases the perceived stress helps to limit the females from stressing themselves further and not allowing their blood pressure to rise further. This study supports the suggestion that stress raises the blood pressure higher than what it is before stress sets in [1].

Stress will therefore increase the mean blood pressure of a stressed group and thus the number of subjects in the group with blood pressure higher than normal. If the mean blood pressure level of a group increases after an event, the level of stress experienced by the group can be said to have increased. Finding the mean of the systolic blood pressure of a group may thus make it possible to compare the various levels of stress experienced by different groups after different events.

The result in Table III shows that the systolic blood pressure was significantly higher at two weeks to the examination than at four weeks after it or when the students just resumed for the term. The increased pressure just before 
the exam may additionally be due to the stimulation of the adrenergic nervous system that may lead to the release of catecholamine and in particular nor-adrenaline at the synaptic neuron and also adrenaline or epinephrine from adrenal medulla [23], [28], making the students to be more nervous and leading to the activation of the sympathetic nervous system to release more hormones into the blood stream with a consequent increase of blood pressure.

Increase in blood pressure related to stress can be dramatic. Once the stressor disappears, the blood pressure slowly returns to normal. The drop in the systolic blood pressure after the examination may therefore be explained to be due to the decrease in the stimulation of the adrenergic nervous system and the reduction of the sympathetic drive to the heart which leads to low cardiac output in response to the reduced stress [28].

In the result shown in Table IV, the diastolic blood pressure which is the minimum pressure during the ventricular diastole did not vary much from one another, two weeks after resumption, two weeks to the examination and four weeks after the examination, as the test of homogeneity for the three groups show that $\mathrm{F}=6.55(\mathrm{P}<0.05)$.

\section{CONCLUSION}

This study adds to the body of knowledge concerning students' examination stress and how to estimate them for groups acting under the same stressor. Further research on examination stress needs to examine the stress experienced from one class to the other and follow the same set of students as they move from the lower class to the upper classes. The same method can be used to compare the examination stress in different schools, and the knowledge of this will be very helpful to the school counselors and health educators. Because the findings show that males and females differ in their experience of stress imposed by academic examination, future studies may also deeply investigate the impact of gender on academic stress.

\section{ACKNOWLEDGEMENT}

The authors are grateful to the Principal of Oroke High school, Akungba - Akoko Ondo State, Nigeria, who allowed student volunteers from his school to participate in the study, the 2017/2018 three hundred level Health Education students of Adekunle Ajasin University, who participated in taking the data, Mr A. Ebiwonjumi of the Department of Mathematical Sciences, Adekunle Ajasin University, who helped with the statistical analysis and Dr. O.S. Daso of the Adekunle Ajasin University Health Center, for making valuable suggestions regarding the discussion of this study.

\section{ETHICAL CONSIDERATION}

Informed consent of each subject, ethical and official approval from the local research ethics committee of the Department of Human Kinetics and Health Education, Faculty of Education, Adekunle Ajasin University Akungba Akoko was obtained for the study and the investigation was performed in accordance with the principles outlined in the declaration of Helsinki.

\section{REFERENCES}

[1] F. Qureshi, J. Alam, M. A. Khan, G. Sheraz, "Effects of examination stress on blood cell parameters of students in a Pakistan medical college", Journ. Ayub Medical College Abbottabed, vol. 14(1), pp. 20 $-22,2002$.

[2] K. W. Dawn, K. Wendy, T. L. P. Nicol, A. S. Domenica, "Violence exposure, catecholamine excretion blood pressure, nondipping status in African American male versus female", Psychosomatic Medicine, vol. 64, pp. 906-915, 2002.

[3] S. G. Sheps, Mayo clinic on high blood pressure: taking charge of your hypertension, 2nd ed. Rochester, MN, Mayo Clinic Health Information, 2002.

[4] T. G. Pickering, G. A. Harshfield, H. Kleiner, S. Blank, J. H. Largh, "Blood pressure during normal daily activities, sleep, and exercise: comparison of values in normal and hypertensive subjects", JAMA, vol 247, pp. 992-995, 1982.

[5] C. Douglas, D. S. George, J. S. Martin, "Blood pressure reaction to acute psychological stress and future blood pressure status: A 10 years follow-up of men in the Whitehall II study", Psychosomatic Medicine, vol. 63, pp. 737-743, 2002.

[6] J. Richlin-Klonsky, and R. Hoe, Sources and Levels of Stress among UCLA. Student Affairs, Briefing, 2, 2003.

[7] J. H. Humphrey, D. A. Yow, and W. W. Bowden, Stress in College Athletes: Causes, Consequences, Coping. Binghamton, NY: The Haworth Half-Court Press. An imprint of the Haworth Press, Inc., 2000 .

[8] R. S. Lazarus, and J. B. Cohen, "Environmental Stress", Human Behavior and Environment, Plenum, N.Y., 1977, pp. 89-127.

[9] K. Fairbrother and J. Warn, "Workplace dimension Stress and Job satisfaction", Management Psychology, vol. 18(1), pp. 8-21, 2003.

[10] J. A. Carveth, T. Gesse, and N. Moss, "Survival strategies for nurse midwifery students", Journal of Nurse Midwifery, vol. 41, pp, 50-54, 1996.

[11] R. Abouserie, "Sources and levels of stress in relation to locus of control and self esteem in university students", Educational Psychology, vol. 14, pp. 323-330, 1994.

[12] J. P. Kohn, and G. H. Frazer, "An academic stress scale: Identification and rated importance of academic stressors", Psychological Reports, vol. 59, pp. 415-426, 1986.

[13] D. Krause, "The first year experience in Australian Universities. Findings", 2005.

[14] H. I. Kaplan, and B. J. Shadock, Learning theory. In Synopsis of Psychiatry: Behavioural Sciences/ Clinical Psychiatry, 8th ed., 2000, pp. 148-152.

[15] P. M. Niemi, and P. T. Vainiomaki, "Medical Students' Academic Distress, Coping and Achievement Strategies during the Pre-Clinical Years" Teaching and Learning in Medicine", vol. 11, pp. 125-134, 1999.

[16] A. J. Elliot, M. M. Shell, K. B. Henry, M. A. Maeir, "Achievement goals, performance contingencies and performance attainment. An experimental test", Journal of Educational Psychology, vol. 97 (4), pp. 630-640, 2005.

[17] M. Hofer, "Goal Conflict and Self-Regulations: A New Look at Pupils' Off-Task Behavior in the Classroom", Educational Research Review, vol. 2 (1), pp. 28-38, 2007.

[18] S. B. Robbins, J. Allen, A. Casillas, C. H. Peterson, and H. Le, "Unraveling the Differential Effects of Motivational and Skills, Social, and Self-Management Measures from Traditional Predictors of College Outcomes", Journal of Educational Psychology, vol. 98 (3), pp. 598616,2006

[19] WHO. (2008). Revised draft: Global action plan for the prevention and control of noncommunicable diseases: 2013-2020.World Health Organization. [Online]. Available: http://www.who.int/nmh/events/2013/revsed_draft_ncd_actionplan.pd f.

[20] J. I. Markovitz, K. A. Matthews, R. R. Wing, L. H. Kuller, and E. N. Meilahn, "Psychological, biological and health behavior predictors of blood pressure changes in middle-aged women", J Hypertens, vol. 9 , pp. 399-406, 1991

[21] S. Khoshemehry, A. Khanmohammadi, M. E. Bahram, "The effect of stress on blood pressure and heart rate of High School girls", Int. Journ. of Sport studies, vol. 4 (4), pp. 448-451, 2014.

[22] P. A. Thoits, "Stress, coping and social support processes; Where are we? What next?", Journal of Health and social behavior, vol. 35, pp. 53-79, 1995.

[23] B. Sharma, "A study of academic stress and its effect on vital parameters in final year medical students at SAIMS Medical College, 
Indore, Madhya Pradesh", Biomedical Research, vol. 22 (3), pp. 361$365,2011$.

[24] L. Dusselier, B. Dunn, M. C. II. Shelly, and D. F. Whalen, "Persona Health academic and environmental predictors of stress for residence hall students", Journal of American College Health, vol. 54 (1), pp. 15 $24,2005$.

[25] B. Eun-Jun, "The effect of gender, Academic concerns and social support on stress for international students". PhD Thesis, University of Columbia, 2009

[26] M. P. Matud, "Gender differences in stress and coping styles", Personality and Individual differences, vol. 37 (7), pp. 1401- 1415, 2004.

[27] S. Mohsin et al., "Perceived stress sources and the severity of stress among medical undergraduates in a Pakistani Medical school", $B M C$ Medical Education, 10, 2, 2010.

[28] T. A. Al-Sandook, M. T. Al-Nuaimy Karama, M. T. Al- Saffar, "Effect of stress on arterial Blood Pressure in dental students", Al-Rafidain Dental Journal, vol. 7, pp.118-121, 2007.

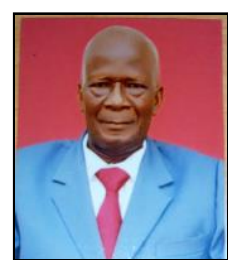

Prof. Nathaniel O. Ajayi was born in Ajowa, Akoko N-W LGA, Ondo State, Nigeria in January 13, 1942. $\mathrm{He}$ attended University of Ibadan, Nigeria and University of Uppsala, Sweden (Post Doctorate) where he obtained B.Sc. (Hons. Physics.), Ph.D. (Physics) and Postdoctoral Diploma of International Seminar (Biophysics) between 1965 and 1975.

He was a LECTURER, Physics Department, University of Benin, Benin City, Nigeria between 1971-2007 and currently a LECTURER, Department of Physics and Electronics, Adekunle Ajasin University, PMB 001 Akungba Akoko. Ondo State, Nigeria. from January 2010 till date. He has published several articles in local, national and International journals.

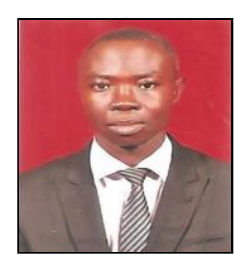

Dr. Joseph S Adegboro was born in Owo loca government area of Ondo State Nigeria on 21st of February 1965. He attended Ondo State School of Nursing Akure, University of Nigeria Nsukka between 1993 and 1998 for his B Sc. in Health Education; University of Benin, Benin City Nigeria between 2003 and 2012 for his M.Ed. and Ph.D in Community Health Education.

He worked with Ondo State Hospital Management Board as a NURSING OFFICER between 2000 and 2009, and he joined the service of Adekunle Ajasin University Akungba Akoko, Ondo State, Nigeria in 2009 as a LECTURER II and has risen to the position of a SENIOR LECTURER. He has published over 30 research works in local, national and international journals and textbooks

His research interest is in the area of Community Health Education, Health Promotion, and epidemiological studies of communicable and non communicable diseases.

Dr. Adegboro is a life member of the following professional associations: Nigerian Association of Health Educators (NAHE); Teachers Registration Council of Nigeria (TRCN) and Teaching and Education Research Association (TERA). 